\title{
Rediscovery, taxonomy and conservation of the Anjouan Scops Owl Otus capnodes (Gurney 1889)
}

\author{
ROGER J. SAFFORD
}

\section{Summary}

The Anjouan Scops Owl Otus capnodes, not recorded with certainty since about 1886 , was rediscovered in June 1992. It has usually been treated as a race of Madagascar Scops Owl Otus rutilus but, judging from plumage and especially voice, it is a distinct species. It is found only in the remaining patches of upland forest (above $800 \mathrm{~m}$ ) on Anjouan (Ndzuani), Comoro Islands, where the population is estimated to be at least several tens of pairs, probably between 100 and 200 pairs. The species is highly endangered by accelerating forest clearance and capture for food by the huge and increasing human population. Long-term environmental programmes are essential but may be too late to save this and other endangered species on Anjouan. Species-specific actions are needed: for the owl, a translocation to the neighbouring island of Moheli should be investigated.

La chouette Scops d'Anjouan Otus capnodes, qui n'avait pas été observée avec certitude depuis environ 1886, a été redécouverte en juin 1992. Elle était habituellement considérée comme appartenant à la race des chouettes Scops de Madagascar Otus rutilus, mais à en juger par son plumage et surtout par sa voix, c'est une espèce différente. Elle n'existe que dans les restants de forêts d'altitude (plus de 800 mètres) en Anjouan (Ndzuani), dans les Iles Comores, où la population est estimée à au moins plusieurs dizaines de couples, probablement entre 100 et 200 paires. L'espèce est fortement menacée par l'accélération de la déforestation et la capture de ces oiseaux pour l'alimentation d'une population humaine très nombreuse et croissante. Des programmes de conservation de l'environnement à long terme sont essentiels, mais arriveront peut-être déjà trop tard pour sauver cette espèce et d'autres espèces menacées en Anjouan. Des actions spécifiquement centrées sur chaque espèce sont nécessaires: pour la chouette, la possibilité d'un transfert sur l'île voisine de Mohéli devrait être examinée.

\section{Background}

Between 1884 and 1886 , an indefatigable French traveller, $\mathrm{H}$. Humblot, collected bird specimens on the Comoro Islands. Milne-Edwards and Oustalet (1888) reported that Humblot had collected 17 scops owl specimens from Anjouan (Ndzuani) and Mayotte (Maore), and they placed them, along with those of Madagascar, in Otus manadensis (Quoy and Gaimard, Sulawesi). Gurney (1889) compared five Anjouan specimens (then in the University Museum of Zoology, Cambridge [UMZC], and the Norwich Castle Museum) with nine Madagascar specimens (by now known as Otus rutilus [Pucheran]), and described the Anjouan birds as a separate species, Scops (now Otus) capnodes. However, all 
recent authors (e.g. Peters 1940, Benson 1960, Clark et al. 1978, Louette 1988a, Marshall and King 1988) have considered capnodes to be a subspecies of $O$. rutilus.

Subsequent visitors to Anjouan failed to find any scops owls, although $\mathrm{K}$. Curry-Lindahl (in Clark et al. 1978: xii) gave, without details, 1897 as the year of the last sighting. There is no evidence that Naidoo found them in 1906-1907 (Benson 1960). Benson (1960) himself spent from 27 September to 21 October 1958 on Anjouan, without finding any. He traced 33 specimens of the owl in the British Museum (Natural History) (BMNH), the Muséum National d'Histoire Naturelle (Paris) and American Museum of Natural History; all may have been collected by Humblot, and there may be more in other museums. This led Benson to speculate whether over-collecting had caused the bird's extinction.

Louette (1988a and verbally 1992) reported that a scops owl was heard by $\mathrm{M}$. Herremans, a member of the Belgian Zoological Expedition, on the Col de Patsi, Anjouan, on 24 and 28 October 1983 and that, in 1980 , one was caught by, or for, J. C. Remy, who attributed its rarity to hunting for food. The 1983 calls were stated by Herremans (1988) to be very distinct from Otus rutilus mayottensis Benson 1960, of Mayotte. The latter sounds like nominate rutilus (Benson 1960). Herremans (1988) was convinced that capnodes still survived, but neither he nor Louette described the call that was attributed to it.

Subsequently the Grand Comoro Scops Owl Otus pauliani was studied by Herremans et al. (1991), who confirmed Benson's (1960) suspicion that it was a good species, very distinct from Otus rutilus. However, the Anjouan bird remained enigmatic.

\section{Records in 1990 and 1992}

\section{Rediscovery}

From 16 to 19 April 1990 M. I. Evans and I visited the forested uplands of Anjouan, mainly to search for Livingstone's fruit bat Pteropus livingstonii. We camped by the shore of Lac Dzialandze, a remote crater lake at $900 \mathrm{~m}$ elevation with remnants of the indigenous moist evergreen forest on the steep inner walls of the crater. Each night, from dusk to dawn, totally unfamiliar, whistling calls were heard but in the atrocious weather conditions (dense mist and heavy rain) we were unable to see the callers. The most likely possibility seemed to be a seabird (Safford and Evans 1991), although it sounded quite unlike any western Indian Ocean breeding seabird (pers. obs., excepting the Réunion Black Petrel Pterodroma [Pseudobulweria] aterrima, whose call is unknown) or any extant Pterodroma petrel species (V. Bretagnolle in litt. 1992).

I returned to Lac Dzialandze from 14 to 16 April 1992, to be greeted by identical weather. The callers were still present, behaving exactly as they had done in 1990. I recorded them but got no response to tape playback or imitation of the call, possibly as they were too distant. I still had not seen the caller and its identity remained completely baffling given my by now wide experience of wildlife in the western Indian Ocean. Lacking time and money, I had to move on.

The third visit to Anjouan took place from 12 to 19 June 1992. In Dindi, the 
highland village closest to Lac Dzialandze, I met Ahmed Yatima ("Babushon"), a 77-year-old revered for his knowledge of local wildlife (for example, he was unusual in making the distinction between the two Pteropus fruit bats, P. sechellensis and $P$. livingstonii). He immediately recognized my whistled imitation of the call as "badanga", a rare and elusive nocturnal forest bird, but his description left me little the wiser as to its identity. However, villagers tending crops in the forest occasionally encountered them, and one villager offered to take me to see one that day.

In another remote forest patch, several kilometres from Dzialandze, he had found the bird in a cavity in a huge native tree, but upon arriving there we found that it had now gone. The next day I was taken to a different site by another villager, with the same result. At a third site the day after, a tree that was known previously to have been housing a "badanga" had been cut down. At each site, the mystery birds called as ever (starting between $17 \mathrm{~h} 59$ and 18ho6), but were never close enough to be attracted by tape playback or seen against the twilight sky.

Finally on 16 June two "badangas" were found by a villager at a fifth site, and shown to me. They were instantly recognizable as Anjouan Scops Owls. At dusk the owls left the cavity (at 18 ho6 and 18ho8) and immediately one gave a quiet, drawn-out, harsh screech, quite unlike anything I had heard before. Then, a few seconds after they had been lost to view, the now familiar clear whistle call was heard.

Attempts to mist-net the owls using tape playback of both calls were unsuccessful. At dawn the next morning, a loud whistle call (of the type $I$ had constantly been hearing) was heard from the roost tree, and upon investigation I immediately found an owl in the tree. Both birds then returned to the cavity. Villagers assured me that one could be caught alive and unharmed, and so at ogh 30 one was snared using a noose on the end of a $3 \mathrm{~m}$ pole. It was measured, described and photographed (see Appendix and Figures 4-6), and blood and feather samples were collected. When released, it flew back to the cavity.

\section{Habitat, distribution and ecology}

Owls were heard or seen at the localities in Figure 1. At each site I estimated that up to six birds could be heard giving the whistle call. All were above $800 \mathrm{~m}$ in native forest. In addition, a Bristol University Expedition heard owls (identified from my tape-recordings) while studying fruit bats at two sites between 550 and $600 \mathrm{~m}$ around Houngouni, between Mutsamudu and N'Tingui (S. Wray in litt. 1992). Villagers also said they occurred south-east of Tsimbeo, and confirmed the association with native forest. All four nesting or roosting cavities were in large (diameter at breast height over $50 \mathrm{~cm}$ ), old, native trees festooned with epiphytes, standing on steep slopes. Cavities were inaccessible but the entrances were estimated to be at least $10 \mathrm{~cm}$ across, where large branches had broken off the undersides of trees that were tilted at $45^{\circ}$, and so were presumably formed naturally.

The owl seems to be restricted to the remnant native forest areas, with no sign that it occurs in the exotic lowland vegetation, which, at its richest, is dominated by such trees as coconut Cocos nucifera, mango Mangifera indica and 


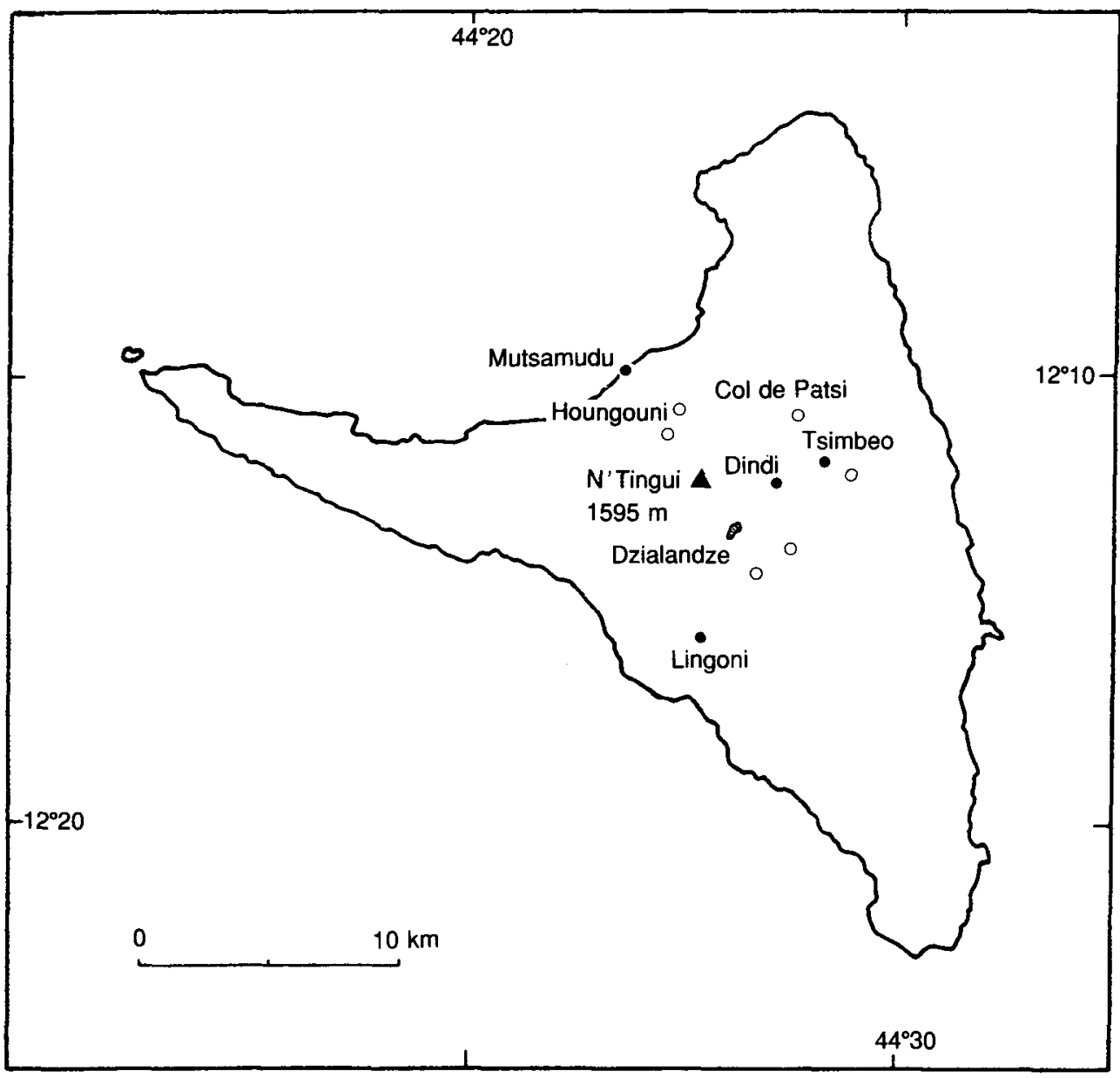

Figure 1. Anjouan, showing localities mentioned in text. Filled circles, town or village; open circles, locality where Otus capnodes has been reported.

kapok Ceiba pentandra. It also appears to be dependent on thick, cavity-forming trees for nesting or roosting; native upland species are probably best.

The only available information on the diet came from Ahmed Yatima, who very plausibly claimed it ate insects.

\section{Voice}

Calls were recorded using a Marantz $\mathrm{CP}_{43}$ cassette recorder and Sennheiser MKH 816 P48 (Figure 2) or Camlink EM 600 (Figure 3) directional microphones, and sonagrams were produced by a Kay $6061 B$ sonagraph. Copies of the recordings have been deposited at the British Library of Wildlife Sounds, London.

The whistle vocalization (Figure 2) consisted of plaintive di- or trisyllabic calls, each transcribed as "peeoo" or "peeooee". Of calls known to me, the trisyllabic call was most reminiscent of a Grey Plover Pluvialis squatarola but with a much 


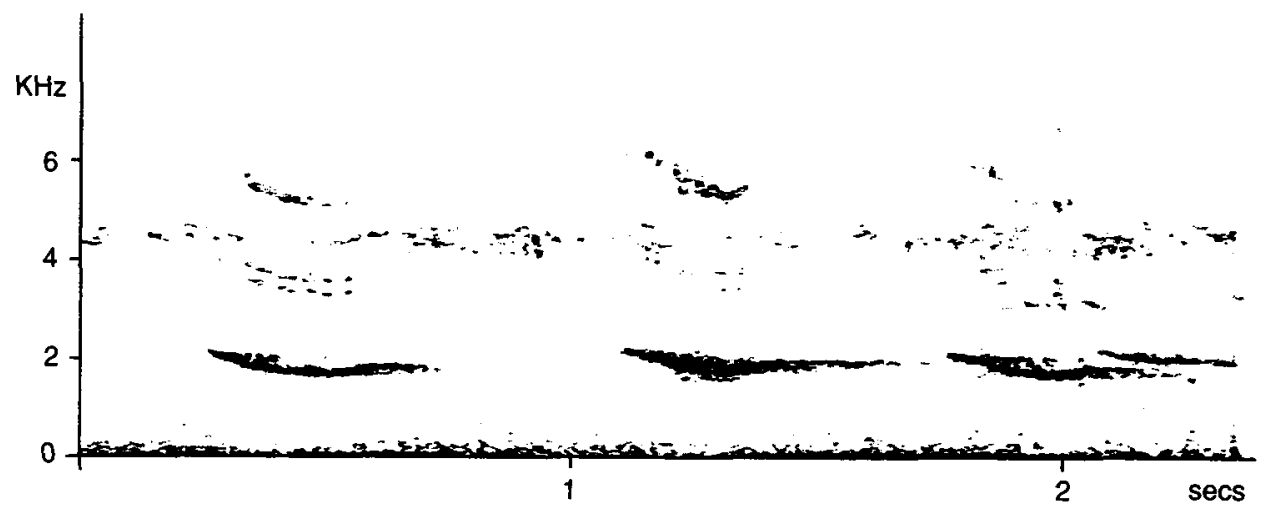

Figure 2. Anjouan Scops Owl Otus capnodes "whistle" calls (45 Hz bandwidth). Anjouan, Comoro Islands, June 1992, R. J. Safford.

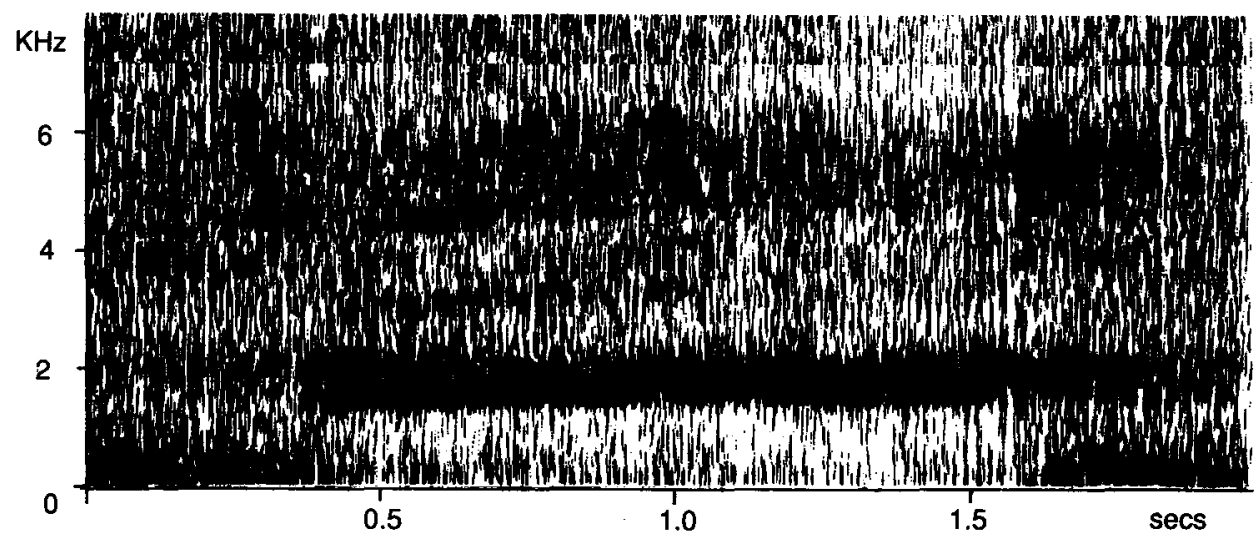

Figure 3. Anjouan Scops Owl Otus capnodes "screech" call (between $0.37 \mathrm{~s}$ and $1.6 \mathrm{~s}$ ) ( $300 \mathrm{~Hz}$ bandwidth). Anjouan, Comoro Islands, June 1992, R. J. Safford.

shorter second syllable. It was somewhat variable in pitch, duration and range (i.e. the difference between the highest- and lowest-pitched notes). Each call lasted 0.35 to $0.51 \mathrm{~s}$ and typically started at around $2,120 \mathrm{~Hz}$, dropped to 1,870 $\mathrm{Hz}$ and tailed off at $1,910 \mathrm{~Hz}$. A typical vocalization consisted of three to five calls uttered at 0.5-1.o $s$ intervals, the interval varying within the vocalization; isolated calls were sometimes uttered. Complete vocalizations were generally separated by at least ten seconds. Calling continued all night, with no clear sign of variation in activity.

Screech calls, heard only once and recorded at close range just after a bird had left the cavity, were quiet and extremely harsh, lasting about $1.5 \mathrm{~s}$. The fundamental note is frequency-modulated around $1,800 \mathrm{~Hz}$ (Figure 3), made harsher by a continuous range of frequencies up to (and perhaps exceeding) $7,000 \mathrm{~Hz}$. Up to 10 notes per minute were recorded, at intervals down to $5 \mathrm{~s}$. 


\section{Morphology}

The Anjouan Scops Owl has been well described by Benson (1960), who found two "phases", referred to here as morphs. Morph A (19 specimens seen by Benson) has a relatively well-marked head, with fine bars on the underparts, while morph B (seven specimens) is one of the most distinctive of all scops owl plumages, being extremely dark chocolate, looking finely grizzled rather than barred or streaked, with the actual markings barely discernible. The two morphs are variable, but no true intermediates are known.

The two birds seen in 1992 were unquestionably the same taxon as the 14 Anjouan specimens I have seen at BMNH and UMZC. The trapped bird (Figures $4^{-6)}$ was the pale morph (Benson's A) and the other was dark. Key characters are summarized in Table 1, along with those of other Comorian and Malagasy scops owls, and detailed descriptions are given in the Appendix. Measurements of my capnodes fall within the ranges given by Benson (1960); in life Benson's wing measurements would probably have been a few $\mathrm{mm}$ longer. At no stage did I see any trace of ear tufts, even when the birds were alarmed; instead, inconspicuous, whisker-like feathers pointed backwards (rather than upwards) from the top corners of the facial disc.

\section{Discussion}

\section{Voice}

Although I knew of the Anjouan Scops Owl's possible existence, the whistle call is so unlike that of any other scops owl that I had thought it unlikely to be one. Since I did not actually see the owl giving this call, could the whistle call have been made by another, still unidentified species? Apart from my own observations (above), all villagers were adamant that the calls were made by "badanga"; those who saw the owls with me were equally adamant that we were watching "badanga". On return to Dindi others also identified my field sketch as "badanga", and confirmed that it made the whistle. I played recordings of the two calls (whistle and screech) to Ahmed Yatima, who identified both as "badanga" as well as the bird I had sketched; unprompted, he reported that the birds leave their cavity at dusk, give the screech call, and then fly off giving the whistling call. My imitation of the call of Madagascar Scops Owl $O$. r. rutilus was considered to be a bad attempt at a Comoro Blue Pigeon Alectroenas sganzini. I asked about other entirely nocturnal birds; the only one described was Barn Owl Tyto alba, known locally as "bwindri" (Louette 1988a gave "bwindi" for Barn Owl on Anjouan) or by the French name, "hibou", but J. T. Marshall (in litt. 1993) confirms that my tape certainly does not refer to this species. Greater and Lesser Vasa Parrots Coracopsis vasa and $C$. nigra have varied whistling calls often heard at night, but, in over 100 nights spent camping within their range elsewhere in the Comoros, Seychelles and Madagascar, I have never heard anything like the whistle attributed here to capnodes.

In August 1992, J. C. Sinclair (in litt. 1992) was shown the same pair of owls as I had seen. At $16 h_{30}$ he played my recording of the whistle call to the roosting birds. The bird at the cavity was "electrified and sat upright with wide open 


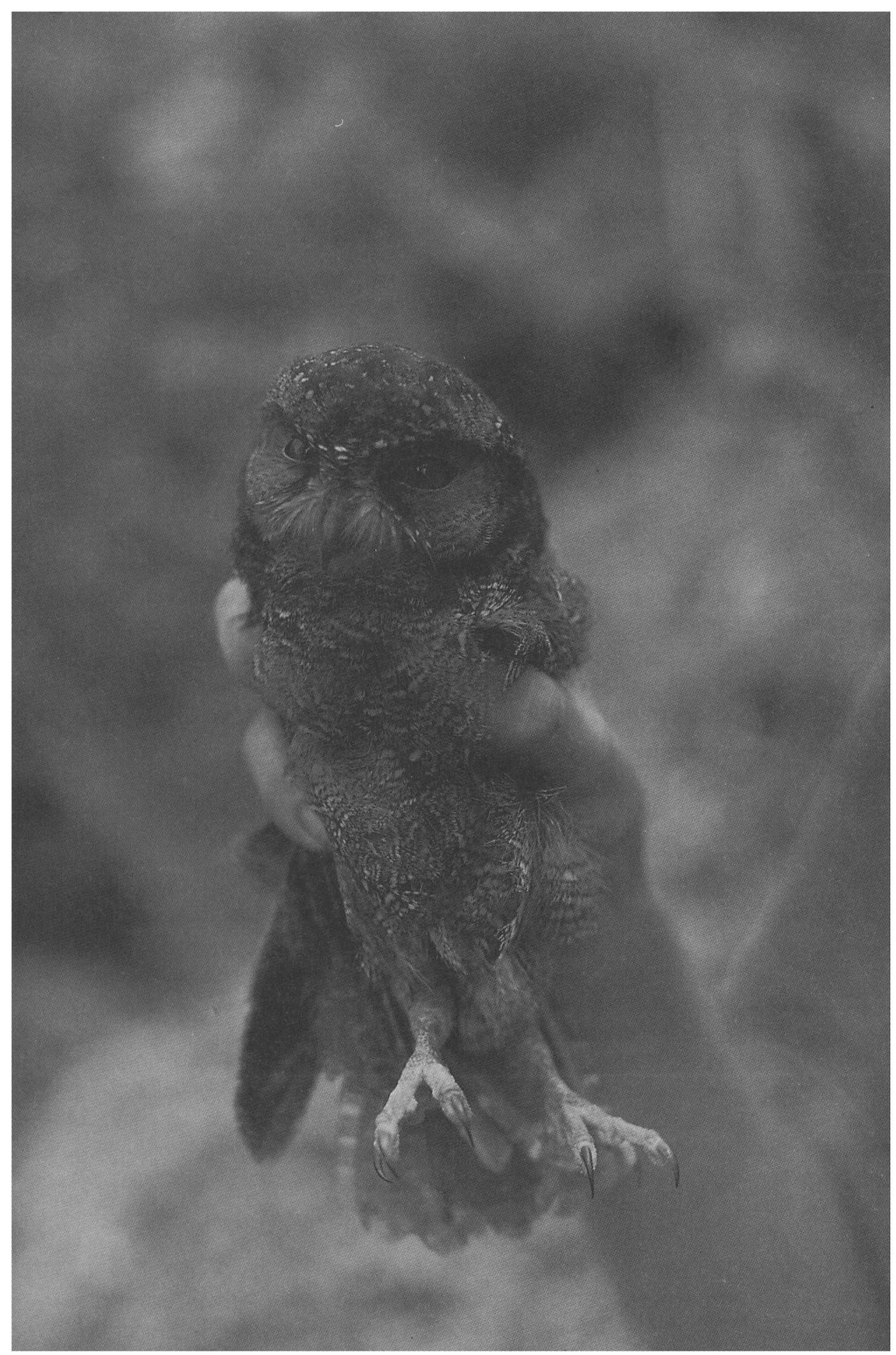

Figure 4. Head and undersides of captured bird, June 1992. Photo: R. J. Safford. 


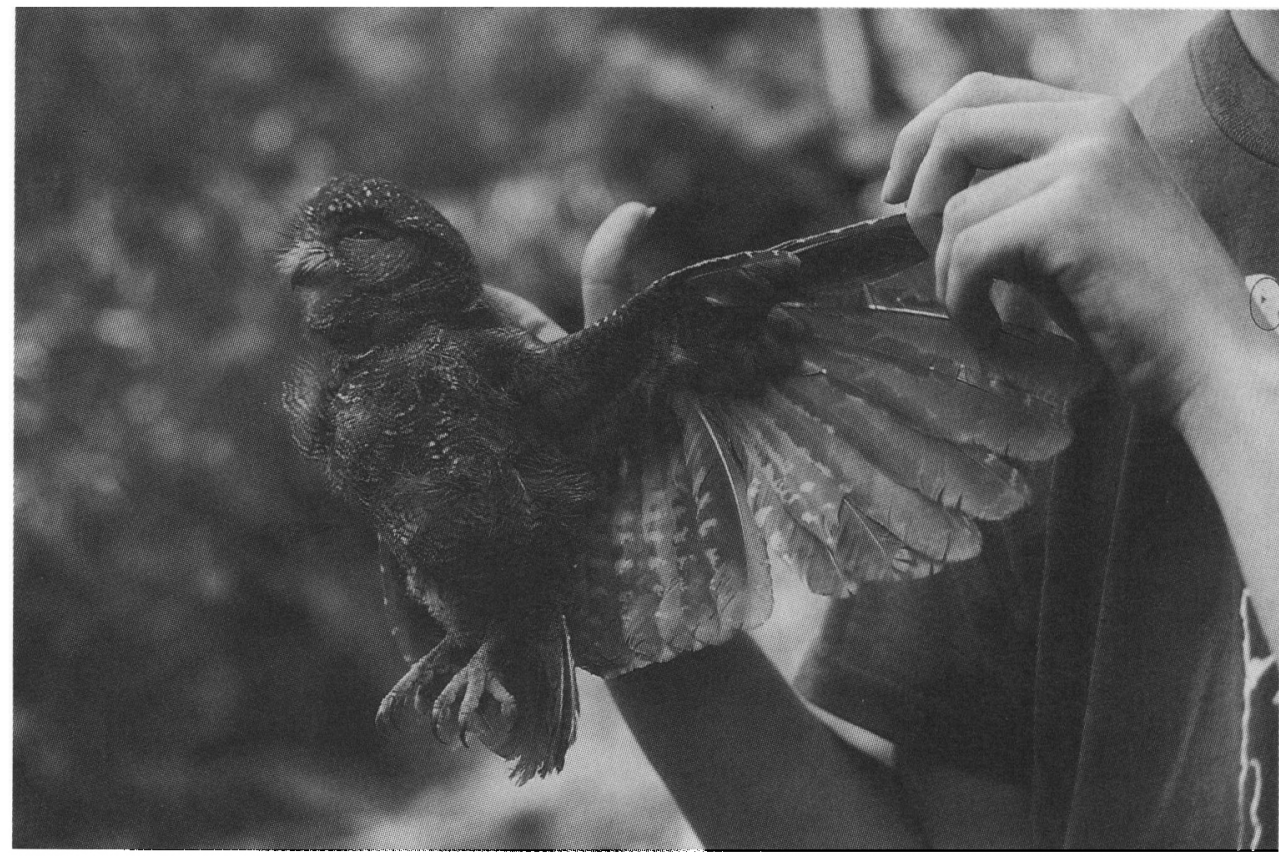

Figure 5. Head, undersides and underwing of captured bird, June 1992. Photo: R. J. Safford.

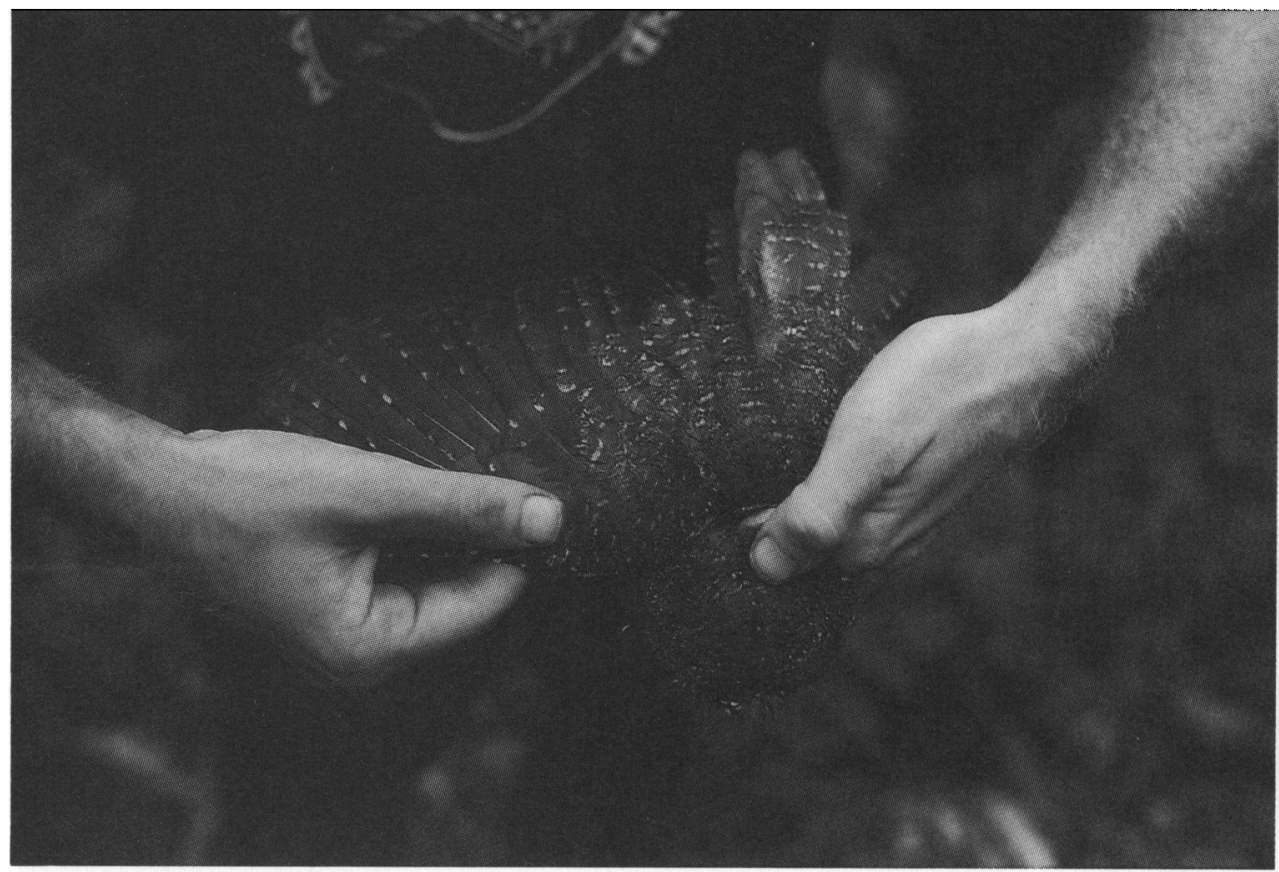

Figure 6. Upperparts and upperwing of captured bird, June 1992. Photo: R. J. Safford. 
eyes and all the time peering around"; its mate burst out of the hole and also peered around, although neither bird was seen to answer the recording. A whistle was, however, heard by J.C.S. as he was leaving the site.

The failure of Benson (1960) to find the bird requires comment, as does his oft-cited (e.g. Marshall 1978) suggestion that over-collection by Humblot might have caused the bird's extinction. The unusual call may explain this. If overcollection had reduced the population so much that Benson could not find birds over 70 years later, it is hard to see how the population could only then have recovered to 1992 levels. It seems more likely that the bird was numerous during Humblot's time, allowing the collection of many specimens without gravely endangering it. The number of birds $I$ heard in the native forest relicts also suggests a reasonable density. I suggest that the owls have always been as common as the habitat area permits, and that if Benson did hear them, he, like myself, never suspected that he was listening to an Otus.

\section{Comparison with other Otus taxa}

Photographs, descriptions and measurements of 14 capnodes specimens (12 in BMNH, two in UMZC; the three Norwich specimens are now in BMNH), plus my own material, have been compared with the following.

O. pauliani (Grand Comoro): pers. obs. (several heard and one seen well by torchlight at La Convalescence, Grand Comoro, on 20 June 1992; own sonagrams; the type and only specimen in BMNH); Benson 1960 (description); Herremans et al. 1991 (description, photographs and sonagrams).

O. rutilus mayottensis (Mayotte): pers. obs. (four specimens in BMNH); Benson 1960 (description).

O. r. rutilus (Madagascar): pers. obs. (heard calling many times in Madagascar; 37 specimens in BMNH and UMZC); Benson 1960 (description); Marshall 1978 (recordings).

O. pembaensis (Pemba, sometimes treated as a subspecies of $O$. rutilus): pers. obs. (seven specimens in BMNH); Benson 1960 (description).

Seychelles, Asian and African taxa: pers. obs. (field experience of $O$. insularis, $O$. scops, $O$. senegalensis, $O$. leucotis and $O$. brucei; specimens of most taxa in BMNH); Marshall 1978 (Asian recordings, e.g. O. bakkamoena, O. manadensis).

No Seychelles, African or Asian taxon approached capnodes (or, incidentally, pauliani), morphologically or vocally. In fact the whistle call was completely unlike any other Otus species known to me, even allowing for the considerable variation known in the calls of some taxa (e.g. O. r. rutilus: pers. obs.). The screech call is a more credible Otus noise, but is much higher-pitched than the equally disagreeable "sawing" note of Seychelles Scops Owl O. insularis. A possibly similar-sounding call (perhaps homologous in function) was heard from a male O. r. rutilus in breeding condition, collected by Benson et al. (1976) near Sakaraha, Madagascar: it was a "harsh, guttural 'k-r-r-r-k', immediately repeated some four times" (quotation from Benson's original English language manuscript), and different from the call Benson (1960: see below) heard on Mayotte and elsewhere in Madagascar. However, J. T. Marshall (in litt. 1993) knows of no other owl call that sounds like either of the calls of capnodes.

The taxa rutilus and mayottensis are close in voice and morphology, as noted 
by Benson (1960). O. pembaensis is distinctly plain and warm-coloured. From Pakenham's (1937) description, Benson (1960) and Kemp (1988) (q.v. for biometrics) concluded that the call of pembaensis was similar to that of rutilus (a series of 3-10 "hooo" notes), but Burton (1984) described it as a series lasting much longer and Pakenham (1979) stated that the call was quite distinct from that of rutilus, but did not elaborate.

Whereas capnodes and mayottensis are large (the latter also long-billed), pauliani is strikingly small - my capnodes was $71 \%$ heavier and $20 \%$ longer-winged than the pauliani specimen described by Herremans et al. (1991), but note the sexual dimorphism shown in the weights of rutilus given in Table 1. Benson (1960) considered pauliani to be very distinct, but there is a strong similarity between it and the pale morph capnodes, in the finely barred cream, sepia and buff underparts, dark brown upperside and lack of obvious ear tufts. It differs most by its stronger pale scapular spots, small size and whitish underwing coverts, also showing on the marginal coverts at the carpal joint (capnodes has a very dark underwing: compare Figure 5 in Herremans et al. 1991 with Figure 6 in this account). Both capnodes that I saw had "cat-like" greenish-yellow irides, and three specimen labels note "iris pale yellow"; Benson's and my pauliani also had yellow irides, but Herremans et al. (1991) noted dark eyes on each of five seen.

Table 1. Characters of surviving western Indian Ocean scops owls Otus. Linear measurements in $\mathrm{mm}$, weights in $\mathrm{g}$, means and sample sizes in brackets.

\begin{tabular}{|c|c|c|c|c|c|c|c|}
\hline & Sex & Winga & Culmen $^{a}$ & Weight $^{b}$ & $\begin{array}{c}\text { Tarsus } \\
\text { exposed }\end{array}$ & Main call & Ear tufts \\
\hline \multirow[t]{2}{*}{ pauliani } & $\sigma$ & 141 & 20 & na & $1 / 3$ & $\begin{array}{c}\text { "cho" infinite } \\
\text { series }\end{array}$ & vestigial \\
\hline & $? \sigma^{\prime}$ & 144 & 18 & 69.5 & & & \\
\hline capnodes & o & $\begin{array}{c}15^{8-173} \\
(165.5 ; 29)\end{array}$ & $\begin{array}{c}21-23 \\
(22.0 ; 29)\end{array}$ & 119 & $1 / 3$ & "peeooee" ${ }^{\prime} 5$ & $\begin{array}{l}\text { absent/ } \\
\text { ?vestigial }\end{array}$ \\
\hline \multirow[t]{2}{*}{ mayottensis } & $\sigma^{\prime}$ & $\begin{array}{l}166,170 \\
171,171\end{array}$ & $\begin{array}{l}25,25 \\
26,26\end{array}$ & na & $1 / 6$ & "hooo" $\times 5$ & prominent \\
\hline & 9 & $\begin{array}{l}171,172 \\
173,175\end{array}$ & $\begin{array}{l}25,25 \\
25,26\end{array}$ & na & & & \\
\hline \multirow[t]{3}{*}{ rutilus } & $\sigma$ & $\begin{array}{c}145-161 \\
(153.4 ; 14)\end{array}$ & $\begin{array}{c}20-22 \\
(20.6 ; 14)\end{array}$ & $\begin{array}{c}85,97 \\
105,107\end{array}$ & o/1 & "hooo" $\times 5$ & prominent \\
\hline & q & $\begin{array}{c}149-161 \\
(155.0 ; 11)\end{array}$ & $\begin{array}{c}20-21 \\
(20.5 ; 11)\end{array}$ & 112 & & & \\
\hline & o & $\begin{array}{c}146-166 \\
(154.8 ; 18)\end{array}$ & $\begin{array}{c}19-22 \\
(20.6 ; 18)\end{array}$ & 116 & & & \\
\hline \multirow[t]{2}{*}{ insularis } & $\sigma^{\pi}$ & 163 & 25 & na & $1 / 1$ & rasping croak & small \\
\hline & 0 & 173 & 23 & na & & & \\
\hline \multirow[t]{2}{*}{ pembaensis } & $\sigma^{\prime}$ & $\begin{array}{c}150,151,153 \\
154,155\end{array}$ & $\begin{array}{c}21,21,21 \\
21,23\end{array}$ & na & $o / 1$ & $\begin{array}{c}\text { "hu", sequence } \\
\text { uncertain }\end{array}$ & small \\
\hline & 웅 & 151,151 & 20,22 & na & & & \\
\hline
\end{tabular}

Notes

na, not available.

aAll wing and culmen measurements are from museum specimens measured by Benson (1960), except the second pauliani, which was a live individual caught by Herremans et al. (1991).

bWeights of pauliani from Herremans et al. (1991), capnodes from this study, rutilus from $\mathrm{T}$. S. Schulenberg (in litt. 1993) and (one male) from Benson et al. (1976).

$\mathrm{c} 0 / 1$ means tarsus fully feathered; $1 / 1$ means tarsus bare. 
Indian Ocean Otus taxa differ from each other in the extent of tarsal feathering. $O$. insularis (Seychelles) has almost bare tarsi; pauliani and capnodes both have the lower $10 \mathrm{~mm}$ of the tarsus bare; tarsi of rutilus and pembaensis are fully feathered, and mayottensis is intermediate between rutilus and capnodes in this respect.

Table I summarizes most of these differences and Figure 7 shows the distribution of the western Indian Ocean taxa. The Mauritian commersoni, a large Otus with prominent ear tufts and bare tarsi, has been extinct since about 1840 and no specimens exist (Oustalet 1897).

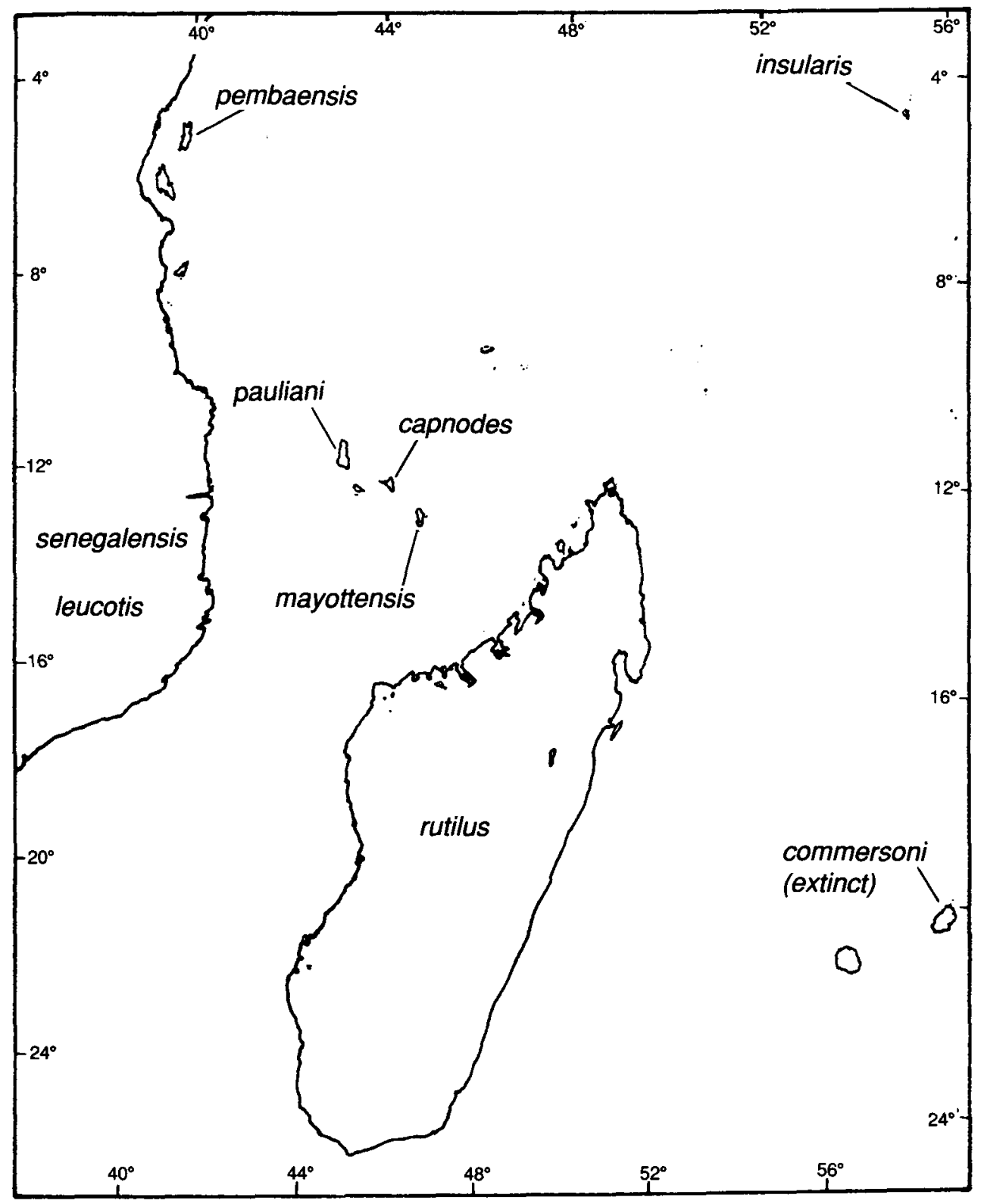

Figure 7. Distribution of scops owls Otus in the western Indian Ocean. 


\section{Taxonomy}

Vocal characters have been used alongside morphology in species-level taxonomy of small owls (e.g. Marshall 1978, König 1991). The Anjouan Scops Owl is very distinctive in its morphology and especially voice. There is as yet no strong evidence for its affinities; while DNA samples from blood and feather samples soon to be analysed may shed further light, it seems certain that it should be considered a full species, Otus capnodes (Gurney 1889), just as its describer suspected. Capnodes is Greek for smoky, giving an alternative English name: Smoky Scops Owl.

Now that the distinctiveness of pauliani and capnodes has been documented, the possibility of pembaensis as a good species also seems more plausible.

\section{Other groups with anomalous biogeography on the Comoros}

The presence of three different and very distinct species of Otus on the Comoros (none is known from Moheli [Mwali]) parallels the situation of the three Comorian drongos Dicrurus, only one of which is a subspecies of the Madagascar form (D. forficatus potior of Anjouan) and where again none is known from Moheli. The Comoros are rich in biogeographical puzzles (e.g. inexplicable absences of some species on some islands), species of uncertain affinities (e.g. Grand Comoro Flycatcher Humblotia flavirostris, Mayotte Drongo D. waldenii) and genera with several species where adjacent mainland areas only have one (e.g. bulbuls Hypsipetes, white-eyes Zosterops: see Louette 1988a,b). Herremans (1988) suggested that the Anjouan Thrush Turdus bewsheri merits specific status (distinct from $T$. comorensis on Grand Comoro and Moheli). More examples, such as the smaller sunbirds Nectarinia (three species divided between four islands), await investigation.

\section{Conservation}

\section{The crisis on Anjouan}

The people and wildlife of Anjouan face one of the worst environmental crises in Africa. In 1958 Benson found the situation "depressing". In 1992 the human population was about 180,000 (CARE-Anjouan per S. Wray in litt. 1992), with about 450 individuals per square kilometre, a colossal density for a predominantly rural population; the current net annual increase is an equally daunting $3.6 \%$ (Weightman 1987, cited in Carroll and Thorpe 1991). An estimated 1,109 ha of primary forest remained in 1987 , from 8,260 ha in 1972 (Weightman 1987, cited in Carroll and Thorpe 1991). Clearance is continuing, starting with removal of all but the largest trees to make room for crops such as bananas and manioc (cassava) even on precipitous slopes (Figure 8), now criss-crossed by paths. There can be little or no forest regeneration, and all primary forest areas I saw seemed to be thoroughly disturbed, and invaded by exotic plants (e.g. Rubus rosifolius, Lantana camara). 


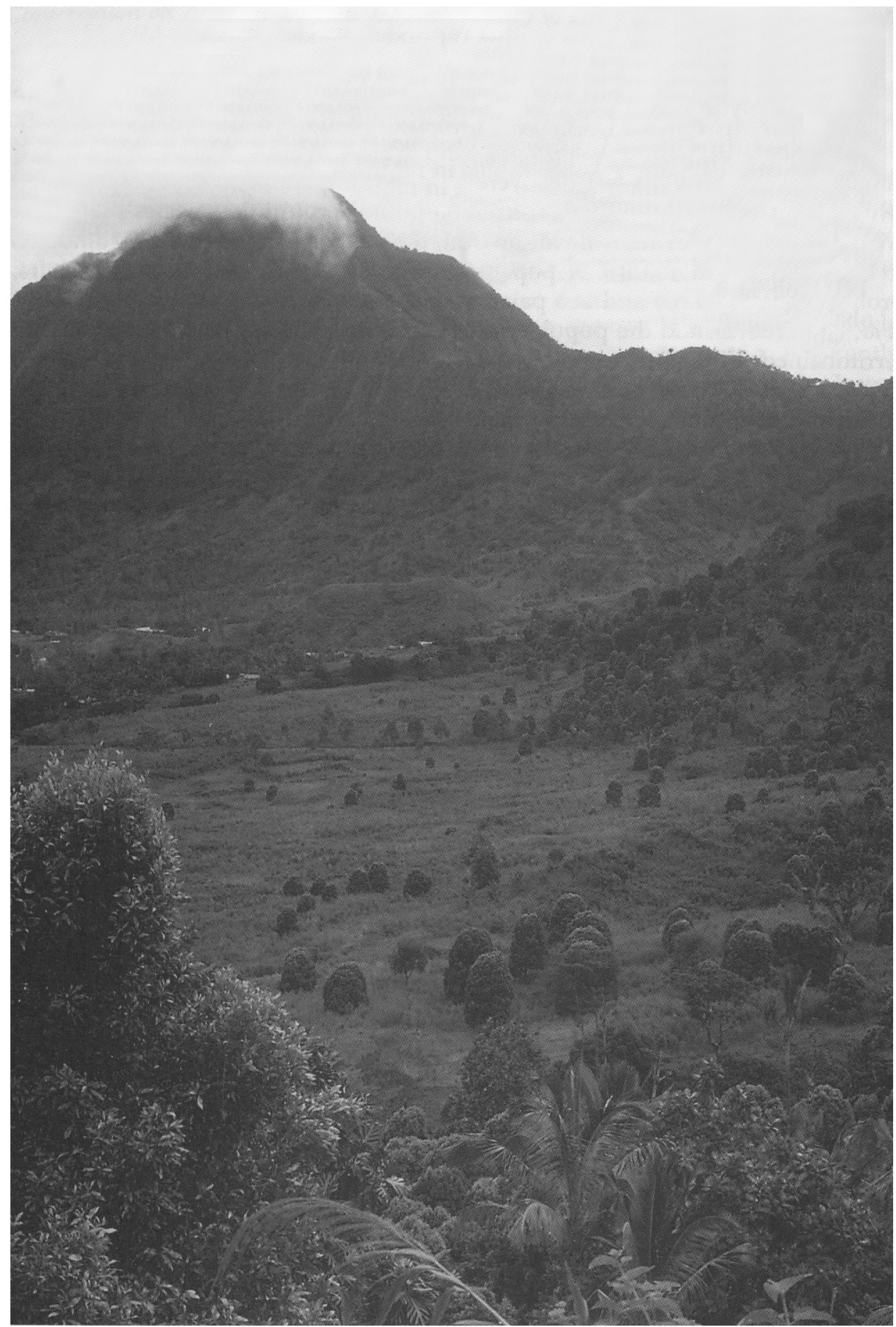

Figure 8. Uplands of Anjouan, showing cultivation and, in the background, forested mountains where Otus capnodes survives. Photo: R. J. Safford. 


\section{Density and population of Otus capnodes, and the threats it faces}

Herremans et al. (1991) and I usually heard four to six of the quieter O. pauliani simultaneously. I heard $O$. capnodes in similar numbers, but the presumed territorial whistle call of $O$. capnodes seemed to carry further than the calls of $O$. pauliani of Grand Comoro or O. rutilus in rainforest in Madagascar (pers. obs.), and suggested that the densities were at most comparable to those of the latter two species, if not somewhat lower. Taking into account the species's presence well below $800 \mathrm{~m}$ elevation at Houngouni, the suitable habitat probably amounts to between 10 and $20 \mathrm{~km}^{2}$. A population size of at least several tens of pairs, probably between 100 and 200 pairs, seems a reasonable estimate. Herremans et al. (1991) estimated the population of $O$. pauliani to be over 1,000 pairs, with territories covering approximately 5 ha.

There appear to be no areas of truly pristine native forest left on Anjouan and so the owl must be able to tolerate the first stages of habitat degradation, but not habitat destruction. The patchy forest relicts are also very vulnerable to cyclones (which occur regularly in the western Indian Ocean), with many trees already listing on shallow, eroded soil. Apart from this continuing principal threat, the species is widely captured for food. It was said to be too rare to be worth special searches, but any encountered are usually taken and Louette and Stevens (1992) considered hunting to be the main threat to its survival. Rats Rattus sp. are abundant in the forest (pers. obs.) and may affect breeding success by nest predation, although there is no concrete evidence.

\section{Other threatened species on Anjouan}

The scops owl is not the only critically endangered species dependent on Anjouan's dwindling forest. Livingstone's fruit bat otherwise occurs in small numbers only on Moheli (rediscovered there in 1989: D. Meirte in Carroll and Thorpe [1990], and in 1992: D. Thomforde, verbally 1992) and its total population in 1992 was between 140 and 200 individuals (S. Wray in litt. 1992). Mongoose Lemur Lemur mongoz is one of the most endangered lemurs, occurring in a small, littleprotected region of north-west Madagascar, with introduced populations on Anjouan and Moheli, where they are not much persecuted and at high (but steeply declining) density (Harcourt 1990). The swallowtail butterfly Papilio aristophontes is endemic to the forests of Grand Comoro, Moheli and Anjouan, and was classified as Indeterminate by Collins and Morris (1985). Among birds, the endemic subspecies of Frances's Sparrowhawk Accipiter francesii pusillus, Cuckoo-roller Leptosomus discolor intermedius and Crested Drongo D. f. potior are all rare (Louette 1988a). The only other endemic bird species, the Anjouan Sunbird $N$. comorensis (considered as a subspecies of the Souimanga Sunbird $N$. souimanga by Louette [1988a], but as a full species by previous authors and also by Sibley and Monroe [1990]) is abundant all over the island (Louette 1988a, pers. obs.). Not surprisingly, little is known of other faunal groups. The forest vegetation itself, poorly studied but doubtless rich in plant species, is of course highly endangered. 


\section{Conservation on Anjouan}

Conservation efforts on Anjouan must take all these species into account. There is at present no protected area on Anjouan, and considering the human population's high density and its dependence on the land, I agree with Louette and Stevens (1992) that it is unlikely that a traditional, strict nature reserve would be feasible. More long-term thinking is reflected in a UNESCO-sponsored family-planning programme (Carroll and Thorpe 1991), the involvement of CARE international in forestry projects, environmental education by the United States Peace Corps, and the formation of a non-governmental, environmental organization (Ulanga).

However it is very doubtful whether these measures will work quickly enough to save the most endangered species. Therefore attempts are currently being made to catch Livingstone's fruit bats for captive breeding by the Jersey Wildlife Preservation Trust, and drastic action is needed if the owl's future is to be secured. A possibility would be to introduce the species to Moheli, where the native forest is much more extensive, human population density far lower and no scops owl is known. Against this, the introduction of a nocturnal, insectivorous bird to an island which has never before supported one could have consequences (not only on the invertebrate fauna) which would be almost impossible to predict. At any rate, the absence of a scops owl on Moheli must first be confirmed by surveys, using local knowledge; there may be no reason for its absence other than a chance failure to colonize. Introduction might be achieved by translocation of wild birds, or with a captive period to boost numbers (several Otus species have bred in captivity and should be suited to known release techniques: P. J. S. Olney verbally 1992).

With arguably the world's most endangered bat and owl, as well as a highly endangered lemur and a human population in deep crisis, Anjouan needs, and deserves, immediate help. Species-specific measures are needed urgently, but it is to be hoped that these species will draw international attention to the desperate plight of the people and ecosystems of this remarkable island.

\section{Acknowledgements}

Greatest thanks go to Mike Evans and Simon Sutton, my companions on the Comoros in 1990 and June 1992 respectively. The International Council for Bird Preservation financed my third visit to Anjouan; Gary Allport, Nonie Coulthard; Mike Evans and Mike Rands were especially helpful. On Anjouan, I enjoyed the hospitality of Kathryn Hunter and David Thomforde ("Wild man'), and also of the Bristol University Comoros '92 Expedition. Vincent Bretagnolle prepared the sonagrams and gave much useful advice. Richard Ranft of the British Library of Wildlife Sounds, London, helped analyse the vocalizations and fitted the sonagrams to axes. A. C. Kemp, A. J. Long, M. Louette, J. T. Marshall, H. Mikkola and T. S. Schulenberg all commented on the first draft of this paper. P. R. Colston (BMNH) and R. J. Symonds (UMZC) gave access to museum skins. J. C. Sinclair allowed me to publish his observations. Finally, the birds could never have been tracked down without the extraordinary efforts and knowledge of the villagers of Dindi. 
Appendix. Description of the bird trapped on 17 June 1992, and notes on its presumed mate

\section{Plumage}

Head Crown feathers with dark sepia centres and grizzled buff edges and a few whitish-cream blobs either side of the shaft. More white blobs on the tips of forehead feathers. Facial discs creamy, made darker by blackish, hairylooking shafts and long black whiskers with white bases between the eyes. Slightly warmer buff supra-orbital ridge and dark surround to facial disc.

Underparts Very finely barred, a mixture of sepia, buff and cream, with creamy bars up to $1.7 \mathrm{~mm}$ thick. Buff more restricted, alternating with the cream but more extensive at the bases of the feathers. Pattern extending to undertail coverts.

Upperparts Nape to uppertail coverts with similar pattern to underparts: fine bars of white, buff and sepia. Less buff, overall more sepia, white bars narrower, so overall looks darker than underparts. One nape feather completely white. One line of scapulars rather better marked, showing more extensive white and especially buff, forming very subtle "braces", brighter than surrounding plumage.

Upperwing All feathers with sepia base colour. Marginal wing coverts mostly pale buff but with sepia areas. Lesser coverts with buff speckling, median coverts with very wavy buff barring. Lowest median coverts had inner webs largely dark, with buff flecking and slight cream towards the tip, outer webs with a creamy buff spot near the tip and a buff bar above this. Greater coverts showed buff flecking on the outer webs, and a single creamy spot near the tip. Largest alula feather had three whitish blobs on its outer edge, second alula feather had two, inner had just a faint buff bar. Outer three primary coverts showed slight buff towards the tip. Tertials mottled or grizzled buff with whitish-buff blobs either side of the shaft. Secondaries showed four or five buff smears down the outer web, and creamy bars on the inner webs. Outer primary with serrated outer edge and five white notches with smaller patches near the tip and close to the base. Second primary slightly emarginated although outer web widened beyond emargination and had six pale blobs along its edge. Subsequent primaries had six pale blobs on the outer web, decreasing to three on innermost primary. Inner webs almost unmarked. Shafts all dark.

Underwing Coverts finely barred sepia and dull buff, except for dark grey primary coverts. Under primaries dark silvery grey; inner primaries had a white fringe below and showed some of the patterning of the upperwing. Secondaries barred below on the inner web, similar pattern to upper surface.

Tail Outer feathers had five wavy white bars extending half-way to the shaft on the outer web. Rest had narrow buff bars, all these bars about $2 \mathrm{~mm}$ wide. Central feathers had four very vague bars, otherwise grizzled buff. 
Bare parts Feathered part of tarsi finely grizzled white, sepia and buff. Feet and bare part of tarsi with very small round scales, dull yellowish-green, toes and soles yellower. Iris a cat-like yellowish-green, with narrow yellowish-cream (dead skin colour) orbital. Bill: culmen and lower mandible horn, cutting edge darker.

\section{Measurements (mm)}

Wing 173; tail 80; culmen to feathering 21.5; bill depth at nostril 12.5; tarsus 33.3; hindclaw 9.2; facial disc width 64; weight $119 \mathrm{~g}$. Outermost long primary fell $46 \mathrm{~mm}$ short of wingpoint, $54 \mathrm{~mm}$ past primary coverts.

\section{Field notes on second individual}

Second bird differed as follows. Overall very distinctively dark earth brown, darker and more finely grizzled: actual markings hardly discernible even at close range, reminiscent of Plain Nightjar Caprimulgus inornatus, but some buff bars visible on flanks. No white seen anywhere on plumage (principal difference from the trapped bird). Facial discs with pale radial whiskers and concentric vermiculated pattern. Similar dark surround to facial disc, then buff/sepia vermiculated supra-orbital ridge and blackish blotches on crown. Mouth pink, not seen on trapped bird.

\section{References}

Benson, C. W. (1960) The birds of the Comoro islands: results of the BOU centenary expedition 1958. Ibis 103B: 5-106.

Benson, C. W., Colebrook-Robjent, J. F. R. and Williams, A. (1976) Contribution à l'ornithologie de Madagascar. Oiseau et R.F.O. 46: 209-242. (English manuscript in ICBP library.)

Burton, J. A., ed. (1984) Owls of the world: their evolution, structure and ecology. Second edition. Glasgow: Peter Lowe/Collins.

Carroll, J. B. and Thorpe, I. C. (1991) Conservation of Livingstone's Fruit Bat. A report on an expedition to the Comores in 1990. Dodo 27: 26-40.

Clark, R. J., Smith, D. G. and Kelso, L. H. (1978) Working bibliography of owls of the world, with summaries of current taxonomy and distributional status. No. 1 of the National Wildlife Federation scientific/technical series. Washington, D.C.: National Wildlife Federation.

Collins, N. M. and Morris, M. G. (1985) Threatened swallowtail butterflies of the world: the IUCN Red Data Book. Gland, Switzerland, and Cambridge, U.K.: International Union for Conservation of Nature and Natural Resources.

Gurney, J. H. (1889) On an apparently undescribed species of owl from Anjouan Island, proposed to be called Scops capnodes. Ibis (6)1: 104-107.

Harcourt, C. (1990) Lemurs of Madagascar and the Comoros: the IUCN Red Data Book. Gland, Switzerland, and Cambridge, U.K.: International Union for Conservation of Nature and Natural Resources.

Herremans, M. (1988) Inter-island variation in bird vocalisations on the Comoros. Proc. VI P.A.O.C.: 281-295.

Herremans, M., Louette, M. and Stevens, J. (1991) Conservation status and vocal and morphological description of the Grand Comoro Scops Owl Otus pauliani Benson 1960. Bird Conserv. Internatn. 1: 123-134. 
Kemp, A. C. (1988) Strigidae, typical owls. Pp. 110-155 in C. H. Fry, S. Keith and E. K. Urban, eds. The birds of Africa, 3. London: Academic Press.

König, C. (1991) Zur Taxonomie und Ökologie der Sperlingskäuse (Glaucidium) des Andenraumes. Ökol. Vögel 13: 15-76.

Louette, M. (1988a) Les oiseaux des Comores, Tervuren, Belgium: Musée Royal de l'Afrique Centrale (Ann. Sér. in $-8^{\circ}$, Sci. Zool. no. 255).

Louette, M. (1988b) Double invasions of birds on the Comoro islands. Proc. VI P.A.O.C.: $77-86$.

Louette, M. and Stevens, J. (1992) Conserving the endemic birds on the Comoro islands, I: general considerations on survival prospects. Bird Conserv. Internatn. 2: 61-8o.

Marshall, J. T. (1978) Systematics of smaller Asian night birds based on voice. Orn. Monogr. 25.

Marshall, J. T. and King, B. F. (1988) Genus Otus. Pp. 331-336 in D. Amadon and J. Bull, eds. Hawks and owls of the world: a distributional and taxonomic list. Los Angeles: Western Foundation of Vertebrate Zoology.

Milne-Edwards, A. and Oustalet, E. (1888) Etudes sur les mammifères et les oiseaux des îles Comores. Nouv. Arch. Mus. Hist. Nat., zième Sér. 10.

Oustalet, E. (1897) Notice sur la faune ornithologique ancienne et moderne des lles Mascareignes et en particulier de l'Ile Maurice. Ann. Sci. Nat., Zoologie 8(3): 1-128.

Pakenham, R. H. W. (1937) Otus pembaensis sp. nov. Bull. Brit. Orn. Club 57: 112-114.

Pakenham, R. H. W. (1979) The birds of Zanzibar and Pemba: an annotated check-list. London: British Ornithologists' Union (Check-list no. 2).

Peters, J. L. (1940) Check-list of birds of the world, 4. Cambridge, Mass.: Harvard University Press.

Safford, R. J. and Evans, M. I. (1991) Observations on the Comoro Islands. Appendix 4 in P. M. Thompson and M. I. Evans, eds. A survey of Ambatovaky Special Reserve, Madagascar. London: Madagascar Environmental Research Group.

Sibley, C. G. and Monroe, B. L. (1990) Distribution and taxonomy of birds of the world. New Haven: Yale University Press.

Weightman, B. (1987) The crisis on Anjouan. Unpublished report to FAO.

ROGER J. SAFFORD

16 Berwyn Road, Richmond, Surrey TW1o 5BS, U.K. 